\title{
Performance of Firm and Board Attributes Nexus: Using Hausman Test Analysis
}

\author{
Adegbola Otekunrin ${ }^{1}$, Tony Nwanji ${ }^{1}$, Damilola Fagboro ${ }^{2}$, Johnson Olowookere ${ }^{3} \&$ Stella Ibitoye $^{1}$ \\ ${ }^{1}$ Department of Accounting \& Finance, Landmark University, Omu-Aran, Nigeria \\ ${ }^{2}$ Department of Accounting, University of Lagos, Nigeria \\ ${ }^{3}$ Department of Accounting, Osun State University, Nigeria \\ Correspondence: Adegbola Otekunrin, Department of Accounting \& Finance, Landmark University, Omu-Aran, \\ Kwara State, Nigeria.
}

Received: September 10, 2020

Accepted: November 22, 2020

Online Published: June 14, 2021

doi:10.5430/ijfr.v12n4p268

URL: https://doi.org/10.5430/ijfr.v12n4p268

\begin{abstract}
With the rise of corporate failures and the conflict of interest arising from shareholders and the management, there have been growing concerns in corporate governance (CG). It is there is ponsibility of the board of director in CG is to oversee the management as well as the firm performance and to make the management accountable to shareholders. Hence this research examines the connection between firms' performance and board features using board size, board independence in addition to board age as a proxy for board characteristics and turnover as a proxy for firm performance. A sample size of 16 consumer goods firms out of a population of 20 consumer goods firms listed in the NSE from 2016 to 2019 was used using a judgmental sampling technique. Secondary data employed was taken out from the sampled firms' annual reports. Hausman test analysis was used to select the appropriate regression model, which is the fixed effect regression model that was utilized to analyse the connection between firms' performance in addition to board characteristics. It is found that firm performance and board independence of the consumer services goods companies in Nigeria are significantly related.The results also confirmed that firm performance and board size of the consumer services goods companies in Nigeria are significantly related. The result indicates firm performance and board education of the consumer services goods companies in Nigeria are not significantly related. Consequently, overall lthe study concluded that firms' performance and board characteristics are related. Also, board characteristics increase board performance which will lead to increase in firms' performances, there by maximizing profit and ensuring efficiency. The study concluded that a company with good board characteristics would help to ensure the maximization of both the shareholders and stakeholders wealth. Hence a proper board characteristic helps to solve the problem of both agency theory and stakeholders' theory.
\end{abstract}

Keywords: board characteristics, firms' performance, national stock exchange

\section{Introduction}

Board characteristics refer to features that can be used to measure the effectiveness and efficiency of corporate boards that are tasked with the overall management of the firm. It is important to ensure good management system which is necessary for good financial performance and have been widely recognized as an essential CG mechanism forattaining success in an organization. Effective board characteristics will help to ensure that shareholders and stakeholders would be able to keep an eye on the deeds of the pinnacle tier administration. Extant literature demonstrates that good corporate governance advance performance of firms while some extant literature demonstrates a contrary association, whereas some extant literature demonstrates no significant link between the variables (Ghabayen, 2012). Citing Roberts, McNulty and Stiles (2005), Olabisi, Kajola, Oladejo, Ojeaga and Abass (2018) also agreed.

The vast number of extant literature examined financial performance correlation with board characteristics due to the importance of corporate governance (Assenga, Aly \& Hussainey, 2018: Eluyela et al., 2019a). Nevertheless, the conclusion of most of these extant literatures cannot be used to generalize for Nigeria which is one developing country whilemost of the extant literature is on developed countries which corporate governance cultures and corporate governance structures are different from that of developing countries. This study is novel in that it used consumer goods firms listed in the Nigeria stock exchange to examine if firms' performance is related to the board 
characteristics. It means to the paramount understanding of the researchers, studies that used consumer goods firms listed in the NSE in this subject are scared. This is one gap in the literature this study seeks to cover.

In addition, some extant literature demonstrates that the performance of firms and the board characteristics are positively related, and some extant literature demonstrates that firms' performance and the board characteristics are negatively related. Hence the connection amid firms' performance as well as the board characteristics is yet to be well- known due to the mixed results of extant literature (Bathula, 2008; Ghabayen, 2012). It is for these reasons that the connection amid the performances of firms in addition to the board characteristics continues to be subject to continuous research and is always drawing huge attention from researchers. This research seeks to cover the dearth in the literature by investigating the connection amid the performance of firms and the board characteristics with the use of Hausman Test analysis empirically. Turnover is used as a measurement of firm performance while board education, board size as well as board independence were used as board characteristics.

\section{Literature Review and Hypotheses Development}

The concept of board characteristics can be seen as a general term; there is no widely used definition (Carcello, Hollingsworth, Klein \& Neal, 2006). Board characteristics refer to features of corporate boards that are tasked with the overall management of the firm. The success or collapse of firms is associated with the role acted by the management and firm governance as a process (Eluyela et al., 2019b). In this review, the features of the board of directors that were examined in addition to this consist of board size, board education and board independence.

\subsection{Board Size}

Companies have directors, in addition to the collective figure of companies' directors is regarded as the board of directors. The numeric figure of all the companies' directors combined is referred to as the board size, and most of the time, they are divided into non-executive directors and executive directors. Yermack (1996), according to Abiola and Lawal (2016) concurred. Klein (1998) and Pfeffer (1972) opined that the performance of companies is enhanced by large board size, but Yermack (1996) is of the opinion that time is wasted and decision making are slow down by large board size hence the performance of companies is hindered by large board size. Also, according to Ebrahim, Abdullah, Faudziah (2012) concurred. Based on the view of this extant literature, this study tested the first null hypothesis as given below:

$\mathrm{H}_{1}$ : Firm performance and board size of the consumer services goods companies in Nigeria are not significantly t related

\subsection{Board Independence}

Akpan and Amran (2014:82) cited Fama and Jensen (1983) and assert that. Also, they cited Kamardin and Haron (2011) and opined that. According to Akpan and Amran (2014:82) citing (Fama, 1980) opined that. Another researcher in this school of thoughts is Heravia, Saat, Karbhari and Nassir (2011). Daidj (2017:95) opined that. The firm executive' actions are scrutinized by part of the daily operation of the company, and neither are they employed by the company. Still, they have a say in the company' development of the strategy. These non-executive directors are referred to as independent director (Clifford \& Evan, 1997). They have no connection with the company apart from directorship. Based on the view of these extant literatures, this study tested the second null hypothesis as given below:

$\mathrm{H}_{2}$ : firm performance and board independence of the consumer services goods companies in Nigeria are not significantly related.

\subsection{Board of Education}

According to Akpan and Amran (2014:82) concurred. These studies include Haniffa \& Cooke (2002), Yermack (2006) as well as Ujunwa (2012). Based on the view of these extant literatures, this study did not differentiate between academics qualifications; this study tested the third null hypothesis as given below:

$\mathrm{H}_{3}$ : Firm performance and board education of the consumer services goods companies in Nigeria are not significantly related.

\subsection{Firms' Performance}

There are many measure use for firms' performance in the extant literature on the connection amid firms' performance in addition to board features and include Tobin's Q, ROE (returns on equity), ROA (returns on assets), profit before interest and tax and turnover to mention but a few (Marinova, Plantenga \& Remery, 2010; Durmadi, 2011; Minguez-Vera \& Martin, 2011; Akpan \& Amran, 2014; Otekunrin, Iyoha, Uwuigbe \& Uwuigbe, 2017; Otekunrin, Nwanji, Agba, Olowookere, Fakile, Lawal, Ajayi \& Falaye, 2018; Otekunrin, Nwanji, Egbide, Fakile, 
Lawal, Ajayi, Falaye \& Eluyela, 2018; Otekunrin, Olowookere, Agba, Fakile, Eluyela, Ajiboye, \& Adama, 2019). However, other firms' performance measures mentioned are somehow derived from turnover, but there is a dearth of literature that used turnover and this study gives to this body of knowledge via employing consumer goods firms listed in the NSE to examine if firms' performance is related to the board characteristics using turnover as a proxy of firm performance

\subsection{Theoretical Underpinnig}

Stakeholder'stheory: The first person to define stakeholder's theory was organizational theorist Ian Mitroff in his book, which was published in 1983 in the California management review by philosopher and management of business administration. Stakeholders' theory is of the view that organisation should consider the interest of all persons, businesses, government and communities impacted by the organisation operations and not just the interest of the shareholders alone should be valued. This is because the organisation is interconnected with all of them. As stated in Olabisi, Kajola, Oladejo, Ojeaga and Abass (2018:11). The Stakeholder theory, unlike the agency and the stewardship theories, advocates the satisfaction of all parties that have a stake in the business rather than the owners alone. Olabisi, Kajola, Oladejo, Ojeaga and Abass (2018:11) cited Freeman (2004). In conclusion, Olabisi, Kajola, Oladejo, Ojeaga and Abass (2018:11) cited Khan and Javid (2011). This is the reason; this study adopted.

AgencyTheory: This involves agent as well as the principal (who are the owner of the firm). The agent represents the principal daily in business transactions because that is the reason why they are employed (Ozordi et al., 2020). Agency theory as postulated in extant study which is premised on the assumption, that there is a separation in management of an organization as well as its ownership. The theory labels the owners of a firm as its principals and the management as its agent. In relation to this study, agents include the management as well as the board of directors while the principals are the shareholders (Daily, Dalton \& Canella, 2003; Yermack, 1996) Owners' interests are likely to be compromised if agents make the most of their egoistic goals at the disadvantage of firm performance. The agents cannot be dependable, and therefore, there is a need for supervision of the executive managers by the board of directors to protect owners' interest. The agency problem arrives when there is goal incongruence between the objectives of the principal and his agent, and it becomes virtually impossible for the principal to keep track of what the agent is up to (Eluyela et al., 2018a; 2018b). Hence the board of directors is there to scrutinize the actions of the management. This is the reason; this study adopted the stakeholder theory

\subsection{Empirical Framework}

Empirical studies using different countries has a connection Yermark (1996) that used United States industrial firms, that used Finland small private firms, Conyon and Peck (1998) that used Netherlands, Denmark, Italy, United Kingdom and France, Hermalin and Weisback (2003), Bonn, Yoshikawa and Phan (2004) that used Japanese firms, Lasfer (2004) that used United Kingdom firms to mention just but a few while Bonn, Yoshikawa and Phan (2004) that used Australian firms and Okiro (2006) that used Kenyan listed firms found no connection between board size and performance. According to Akpan and Amran (2014:82), These studies include Haniffa and Cooke (2002), Yermack (2006) as well as Ujunwa (2012) that use quoted firms in Nigeria to mention but a few. Empirical connection between firms' performance and board size include Fama (1980), Hermalin \& Weisbach (1988), Fama and Jensen (1983), Heravia, Saat, Karbhari and Nassir (2011) as well as Kamardin (2011).

\section{Materials and Methods}

The connection between firm performance as well as characteristics of the BOD of the consumer services goods companies in Nigeria 2012 to 2018 was examined in this study using descriptive research design in line with (Otekunrin et al., 2019a; 2019b; 2018). Sample size of 16 (80\%) consumer goods firms out of a population of 20 (100\%) consumer goods firms listed in the NSE were used due to the availability of data using a judgmental sampling technique (Umukoro et al., 2020). The sample size of 80\% is supported byLaw (2012) that presumes that 30\% of the population could fairly represent the population. Secondary sampled firms' (Adebayo et al., 2020; Eluyela et al., 2020). Analysis is select as appropriate regression, which is the fixed effect regression model.

\subsection{Model Specification}

The independent variables here are board characteristics and firm performance, while the dependent variable is consumer goods. The model used for the study is adopted from the work of Uwuigbe and Olayinka (2012).

$$
\text { TURN }_{\text {it }}=\beta_{0}+\beta_{1} \mathrm{BE}_{\text {it }}+\beta_{2} \mathrm{BS}_{\mathrm{it}}+\beta_{3} \mathrm{BI}_{\mathrm{it}}+\beta_{4} \mathrm{CEO}_{\mathrm{it}}+\beta_{5} \text { Fage } 6 \beta_{5} \text { Fsize }+\mathrm{e}
$$

Where; $\mathrm{BE}=$ board education, $\mathrm{BS}=$ board size, $\mathrm{BI}=$ board independence, $\mathrm{CEO}=\mathrm{CEO}$ duality Fage $=$ firm' age, Fsize = firm' size. 


\section{Results and Discussion}

Table 1. Descriptive statistics

\begin{tabular}{|c|c|c|c|c|c|c|c|}
\hline & TURN & $\mathbf{B E}$ & BS & BI & CEO & FAGE & FSIZE \\
\hline Mean & 92642292 & 0.198095 & 10.63810 & 6.752381 & 63.37516 & 48.26667 & 7.960566 \\
\hline Median & 53710991 & 0.200000 & 11.00000 & 7.000000 & 64.28571 & 50.00000 & 7.967554 \\
\hline Maximum & $9.03 \mathrm{E}+08$ & 0.500000 & 17.00000 & 13.00000 & 87.50000 & 88.00000 & 9.765412 \\
\hline Minimum & 967784.0 & 0.000000 & 4.000000 & 1.000000 & 25.00000 & 8.000000 & 6.508940 \\
\hline Std.Dev. & $1.59 \mathrm{E}+08$ & 0.119277 & 3.135172 & 2.405047 & 13.48552 & 19.08043 & 0.663099 \\
\hline Skewness & 3.585682 & 0.719960 & 0.079898 & 0.230901 & -0.437018 & -0.283642 & 0.462947 \\
\hline Kurtosis & 16.47242 & 3.401944 & 2.287292 & 2.543954 & 2.866582 & 2.823152 & 3.422748 \\
\hline Jarque-Bera & 1019.088 & 9.777804 & 2.334011 & 1.842916 & 3.420103 & 1.544748 & 4.532486 \\
\hline Probability & 0.000000 & 0.007530 & 0.311298 & 0.397938 & 0.180856 & 0.461915 & 0.103701 \\
\hline Sum & $9.73 \mathrm{E}+09$ & 20.80000 & 1117.000 & 709.0000 & 6654.391 & 5068.000 & 835.8594 \\
\hline SumSq.Dev. & $2.64 \mathrm{E}+18$ & 1.479619 & 1022.248 & 601.5619 & 18913.35 & 37862.53 & 45.72881 \\
\hline Observations & 105 & 105 & 105 & 105 & 105 & 105 & 105 \\
\hline
\end{tabular}

Table 1 is a descriptive statics summary of the study. The positive result indicates that the variables skewed to the right. The standard board size is 10.63810 directors, ranging from a least of 4 directors to 17 directors. The minimum of directors that have professional qualification is 0 while the maximum is 5 directors out of 17 directors which thereby imply that they have expert knowledge in financial accounting or financial reporting. The maximum numbers of 13 are independent directors on board out of total 17 directors with an average of 6 directors which then implies that with such quantity of directors on board, the performance of the firms would be fostered and improves firm performance. The minimum and maximum values of CEO duality limit from 25 to 87.5; the average value is 63.37. Firm age has an standard of 48 years ranging from a least of 8 years to a highest of 88 years. The firm size has ranges from a least of 6.50 to a highest of 9.76 , with a standard of 7.96 .

Table 2. HT

\begin{tabular}{llll}
\hline TS & C-S.S & C-S.d & Prob. \\
\hline C-schance & 21.037046 & 6 & $\mathbf{0 . 0 0 1 8}$ \\
\hline
\end{tabular}

Table 2 indicates that the Hausman test. With a probability value of 0.0018 which is less than $5 \%$, it means the FE model is the appropriate model, and the FE Panel Data Regression is given below

Table 3. FixedeffectPDR

\begin{tabular}{lllll}
\hline $\mathbf{V}$ & $\mathbf{C}$ & $\mathbf{S . E}$ & $\mathbf{t}-\mathbf{S}$ & $\mathbf{P .}$ \\
\hline $\mathrm{C}$ & $-4.07 \mathrm{E}+08$ & $2.70 \mathrm{E}+08$ & -1.510992 & 0.1345 \\
\hline BE & 34785248 & $1.90 \mathrm{E}+08$ & 0.182883 & 0.8553 \\
\hline BS & -30042420 & 12339255 & -2.434703 & 0.0170 \\
\hline BI & 40539009 & 19850134 & 2.042254 & 0.0443 \\
\hline
\end{tabular}




\begin{tabular}{lllll}
\hline CEO & -4707085. & 1956185. & -2.406258 & 0.0183 \\
\hline FAGE & 5170902. & 3759866. & 1.375289 & 0.1727 \\
\hline FSIZE & 73809386 & 25178508 & 2.931444 & 0.0043 \\
\hline \multicolumn{5}{c}{ EffectsSpecification } \\
C-sf & & & \\
\hline R-s & 0.839449 & & \\
\hline Adj. R-s & 0.801222 & & 1.270235 \\
\hline F-statistic & 21.95984 & Durbin-Watson stat & \\
\hline P (F-s) & 0.000000 & & & \\
\hline
\end{tabular}

Table 3 is the result of Fixed Effect Panel Data Regression to show the turnover and the independent variables (board' characteristic proxied by education) are related or not related. $84 \%$ (R-squared) variation in the turnover is described jointly via characteristic proxied by as well education. Nevertheless, variables not factored into the study account for $16 \%$. Prob (F-statistic) of 0.000000 is less than $5 \%$, and this indicates a linear connection (firm' proxied by turnover) as well as the (board' characteristic proxied by board size, board independence and board education). Durbin-Watson stat. of 1.270235 indicates low auto-serial correlation.

The first null hypothesis state that firm' performance and board size of the consumer services goods companies in Nigeria are not significantly related. Findings from Table 1 support the alternate hypothesis claim that firm performance and board size of the consumer services are significantly related. This is proved in the prob. value of (0.0170) which is lesser than (0.05) level of significance. The outcome suggests that board size have a significant positive connection on the performance of the sampled consumer services goods company in Nigeria. The study rejects the null hypothesis that says that as firm performance and board size of the consumer services goods companies in Nigeria are not significantly related and accept the alternative hypothesis that says that firm performance and board size of the consumer services goods companies in Nigeria are significantly related. Akpan and Amran (2014), Uwuigbe and Fakile (2012), as well as Hanoku (2008), also provide the same result.

The second null hypothesis states that firm' performance and board independence of the consumer services goods companies in Nigeria are not significantly related. Result based on the Table 1 support the alternate hypothesis that firm performance and board independence of the consumer services goods firms are significantly related. This is proved in the prob. value of (0.0443) which is lesser than (0.05) level of significance. The outcome suggests that board independence have a momentous positive relationship on the performance of the sampled consumer services goods company in Nigeria. The study rejects the null hypothesis that says that as firm performance and board independence of the consumer services firms are not significantly connected and accept the alternative hypothesis that says that firm performance and board independence of the consumer services goods companies in Nigeria are significantly related. Akpan and Amran (2014) differ in their study result but still recommended board independence to Nigeria government as well as regulatory authorities.

The third null hypothesis state that: firm' performance and board education of the consumer services goods companies in Nigeria are not significantly related. Result from Table 1 sustains the null hypothesis. This is proved in the prob. value of $(0.8553)$ which is elevated than $(0.05)$ level of significance. The outcome suggests that board education have an insignificant positive relationship on the performance of the sampled services company. The study accepts the null hypothesis that says that as firm performance and board education of the consumer services goods companies in Nigeria are not significantly related and reject the alternative hypothesis that says that firm performance and board education of the consumer services goods companies in Nigeria are significantly related. Akpan and Amran (2014) differ in their study result. The control construct (CEO and FSIZE) illustrate a significant effect on the performance of sampled purchaser services. This is justified by the prob. value of $(0.0183)$ for CEO variable and (0.0043) for FSIZE variable is greater than (0.05).

\section{Conclusion}

This study concluded that board size as well as board independence have a vital connection with performance proxied by turnover. However, board education does not have a vital connection with performance of listed consumer services firms. When certain board features like board independence, board education, the board size, CEO 
duality can increase their level of performance, it will lead to increased performances in the firm thereby maximizing profit and ensuring efficiency. The results have shown that various board characteristics performance is very crucial in having increased profitability in the firm. Hence a proper board characteristic helps to solve the problem of both agency theory and stakeholders' theory. It has been concluded that a company with good board characteristics will help to ensure the maximization of both the shareholders and stakeholders wealth. This study is limited in the following ways which provide suggestions for further study. First, the study data comprise of listed consumer services firm only. Secondly, the method of data analysis used in the study is panel data regression technique. Subsequent studies can consider the impact of board characteristics on firm performance of other listed companies apart from those in consumer goods. Also, further studies can examine the impact of board features on firm performance both in the long and short run by making use of any co-integration techniques.

\section{Acknowledgement}

All researchers and non-researchers that contributed to this paperare highly appreciated.

\section{Conflict of Interest}

There is no conflicting interest in this study, as any source does not fund it.

\section{References}

Abiola, B. I., Abiola, O. A., \& Lawal, A. A. (2016). Corporate board attributes and auditors' independence: a study of listed deposit money banks. 2016 ICAN, Academic Conference Proceedings, The Institute of Chartered Accountants of Nigeria, 1-1102.

Adebayo, R. F., Eluyela, D. F., Victor-Adisa, A., Olayanju, A., Popoola, O., Maimako, R., ... Dahunsi, O. (2020). Electricity supply and business performance in a Nigerian private university. International Journal of Energy Economics and Policy, 10(3), 497-503. https://doi.org/10.32479/ijeep.8555

Agrawal, A., \& Knoeber, C. R. (1996). Firm' Performance and Mechanisms to Control Agency Problems between Managers and Shareholders. Journal of Financial and Quantitative Analysis, 31(3), 377-397.

Akpan, E. O., \&Amran, N. A. (2014). Board Characteristics and Company Performance: Evidence from Nigeria. Journal of Finance and Accounting, 2(3), 81-89. https://doi.org/10.11648/j.jfa.20140203.17

Assenga, M. P., Aly, D., \& Hussainey, K. (2018). The impact of board characteristics on the financial performance of Tanzanian firms. Corporate Governance: the International Journal of Business in Society. https://doi.org/10.1108/CG-09-2016-0174

Bathula, H. (2008). Board characteristics and firmperformance: Evidence from New Zealand. Unpublished Thesis.

Bonn, I., Yoshikawa, T., \& Phan, P. H. (2004). Effects of Board Structure on Firm Performance: AComparison between Japan and Australia. Asian Business \& Management, 3, 105-125.

Carcello, J., Hollingsworth, C. W., Klein, A., \& Neal, T. (2006). Audit Committee Financial Expertise, Competing Corporate Governance Mechanisms and Earnings Management. Retrieved November 13, 2017, from http://ssrn.com/abstract=887512

Clifford, P., \& Evan, R. (1997). Non-Executive Directors: A Question of Independence. Corporate Governance International Review, 224-231.

Conyon, M., \& Peck, S. (1998). Board size and corporate performance: Evidence from European Countries. Academy of Management Journal, 41(2), 112-123.

Daidj, N. (2017). Strategy, structure and corporate finance: Expressing inter-firm networks and group-affiliated companies. Routledge, Taylor \& Francis Group, London and New York.

Daily, C. M., Dalton, D. R., \& Canella, A. A. (2003). Corporate governance: Decades of dialogue and data. Academic Management Review, 28(3), 371-382.

Darmadi, S. (2011). Board diversity and firm performance: The Indonesian evidence. Corporate Ownership and Control, 9(1), 524-539.

Ebrahim, M. A., Abdullah, K. A., Faudziah, H. B., \& Yahya. A. A. (2012). The Impact of board characteristics on Firm Performance: Evidence from Nonfinancial Listed Companies in Kuwaiti Stock Exchange. International Journal of Accounting and Financial Reporting, 2(2), 310-332. 
Eisenberg, T., Sundgren, S., \& Wells, M. T. (1998). Larger Board Size and Decreasing Firm Value in Small Firms. Journal of Financial Economics, 48, 35-54.

Eisenhardt, K. M. (1989). Agency theory: An assessment and review. International Journal of Management, 5, 341-353.

Eluyela, D. F., Adetula, D. T., Obasaju, O. B., Ozordi, E., Akintimehin, O., \& Popoola, O. (2019a). Foreign directors, indigenous directors and dividend payout structure in Nigerian deposit money banks. Banks and Bank System, $14(2), 1-14$.

Eluyela, D. F., Akintimehin, O. O., Okere, W., Ozordi, E., Osuma, G. O., Ilogho, S. O., \& Oladipo, O. A. (2018a). Datasets for board meeting frequency and financial performance of Nigerian deposit money banks. Data in Brief. https://doi.org/10.1016/j.dib.2018.06.044

Eluyela, D. F., Akintimehin, O. O., Okere, W., Ozordi, E., Osuma, G. O., Ilogho, S. O., \& Oladipo, O. A. (2018b). Board meeting frequency and firm performance: examining the nexus in Nigerian deposit money banks. Heliyon, 4, 850. https://doi.org/10.1016/j.heliyon.2018

Eluyela, D. F., Bassey, I., Oladipo, A. O., Adegboyegun, A. E., Ademola, A., \& Madugba, J. (2020). Impact of capital flight on tax revenue in Nigeria: a co-integration approach. Research in World Economy, 11(5), 141-151. https://doi.org/10.5430/rwe.v11n5p141

Eluyela, D. F., Olajide, D., Tolase, O. A., Okere, W., Ogabi, M., \& Kafidipe, A. (2019b). Impact of gender dichotomy on dividend payout policy in listed Nigerian financial services firm. Cogent Business and Management, 6, 1-10. https://doi.org/10.1080/23311975.2019.1687270

Fama, E. F. (1980). Agency problems and theory of the firm. Journal Political Economics, 88(2), 288-307.

Fama, E. F., \& Jensen, M. C. (1983).Agency problems and residual claims. Journal of Law and Economics, 26, 327-349.

Freeman, R. E. (2004). Stakeholder Theory and CorporateObjective Revisited. Organization Science, 15(3), 364-369.

Ghabayen, M. A. (2012). Board Characteristics and Firm Performance:Case of Saudi Arabia. International Journal of Accounting and Financial Reporting, 2(2), 168-179.

Haniffa, R. M., \& Cooke, T. E. (2002). Culture, Corporate Governance and Disclosure in Malaysian Corporations. Abacus, 38(3), 317-349.

Hanoku, B. (2008). Board characteristics and firm performance: Evidence from New Zealand. Unpublished Thesis.

Heravia, S., Saat, N. M., Karbhari, Y., \& Nassir, A. (2011). Effective Oversight Roles of Board of Directors: The case of listed firms on Bursa Malaysia. World Review of Business Research, 1(1), 231-245.

Hermalian, B., \& Weisbach, M. (2003). Boards of directors asan endogenously determined institution: A survey of the economic literature. Economic Policy Review, 7-25.

Hermalin, B. E., \& Weisbach, M. S. (1988). The determinants of board composition, Journal of Economics, 19, 589-606.

Jensen, M. C. (1993). The modern industrial revolution, exit,and the failure of internal control systems. Journal ofFinance, 48(3), 831-80.

Jensen, M. C., \& Meckling, W. H. (1976). Theory of the firm: Managerial behaviour, agency costs and ownership structure, Journal of Financial Economics, 3(4), 305-360. https://doi.org/10.1016/0304-405X(76)90026-X

John, K., \& Senbet, L. W. (1998). Corporate governance and board effectiveness. Journal of Banking and Finance, $22,371-403$.

Kamardin, H., \& Haron, H. (2011). Roles of Board of Directors: Monitoring and resource dependency perspectives from Malaysia. International Journal of Economics and Accounting, 2(3), 282-306.

Khan, M., \& Javid, A. (2011). Determinants of board effectiveness: Logit model Ferheen Kayani, Interdisciplinary Journal of Contemporary Research in Business, 3(2), 1970-1981.

Klein, A. (1998). Firm performance and board committee structure 1. Journal of Law and Economics, 41(1), 275-304. 
Lasfer, M. A. (2004). On the monitoring role of theboard of directors: The case of the adoption ofCadbury recommendations in the UK. Advances in Financial Economics, 9, 287-326.

Law, T. (2012). Combining qualitative and quantitative approaches: Some arguments for mixed methods research. Scandinavian Journal of Educational Research, 56(2), 155-165. https://doi.org/10.1080/00313831.2011.568674

Lipton, M., \& Lorsch, J. W. (1992). A modest proposal for improved corporate governance. Business Lawyer, 48, 59-77.

Marinova, J., Plantenga, J., \& Remery, C. (2010), Genderdiversity and firm performance: Evidence from Dutch and Danish boardrooms. Discussion paper, University of Utrecht, Utrecht School of Economics, Utrecht.

Okiro, K. O. (2006). The relationship between board size and board composition and firm performance: A study of quoted companies at the NSE. Unpublished MBA Project, the University of Nairobi Organisation for Economic Cooperation and Development.

Olabisi, J., Kajola, S. O., Oladejo, D. A., Ojeaga, P. I., \&Abass, T. F. (2018). Board Characteristics and Performance of Quoted Consumer Goods Firms: Evidence from Nigeria. Journal of Economics and Business Research, 24(2), 7-26.

Otekunrin, A. O., Asamu, F. F., Oye, O. O., \& Olowookere, J. K. (2019a). Current market price of share capital and profitability of selected on Nigerian stock exchange. International Journal of Civil Engineering and Technology, $10(1), 1274-1287$.

Otekunrin, A. O., Fagboro, D. G., Nwanji, T. I., Asamu, F. F., Ajiboye, O. B., \& Falaye, A. J. (2019b). Performance of deposit money banks and liquidity management in Nigeria. Banks and Bank Systems, 14(3), 152-161. https://doi.org/10.21511/bbs.14(3).2019.13

Otekunrin, A. O., Iyoha, F. O., Uwuigbe, U., \& Uwuigbe, O. R. (2017). Adoption of International Financial Reporting Standard, capital structure and profitability of selected quoted firms in Nigeria. Proceedings of the 29th International Business Information Management Association Conference - Education Excellence and Innovation Management through Vision 2020: From Regional Development Sustainability to Global Economic Growth, 3788-3796.

Otekunrin, A. O., Nwanji, T. I., \& Obasaju, B. O. (2018b). Capital Structure and Profitability of Selected Agriculture and Agro-Allied Firms on Nigerian Stock Exchange: Post International Financial Reporting Standard Analysis. International Journal of Civil Engineering and Technology, 9(12), 1615-1625.

Otekunrin, A. O., Nwanji, T. I., Agba, D. Z., Olowookere, J. K., Fakile, S. A., Lawal, S. A., ... Falaye, A. J. (2018a). Effect of Taxationon Corporate Investment: Acase study of Cadbury, Nestleand Federal Inland RevenueService. Proceedings of the $32^{\text {nd }}$ International Business Information Management Association Conference, 7483-7398

Otekunrin, A. O., Nwanji, T. I., Egbide, B., Fakile, S. A., Lawal, A. I., Ajayi, S. A., ... Eluyela, D. F. (2018c). Financial Ratio Analysis and Market Price of Share of Selected Quoted Agriculture and Agro-allied firms in Nigeria after Adoption of International Financial Reporting Standard. The Journal of Social Sciences Research, 4(12), 736-744.

Otekunrin, A. O., Olowookere, J. K., Agba, D. Z., Fakile, S. A., Eluyela, D. F., Ajiboye, B. O., \& Adama, I. J. (2019c). Capital Structure and its determinants: Case of quoted firms in Agriculture and agro-allied sector of the Nigerian economy. Journal of Engineering and Applied Sciences, 14(24), 9667-9676.

Ozordi, E., Eluyela, D. F., Uwuigbe, U., Uwuigbe, O. R., \& Nwaze, C. E. (2020). Gender diversity and sustainability responsiveness: evidence from Nigerian fixed money deposit banks. Problems and Perspectives in Management, 18(1), 119-129. https://doi.org/10.21511/ppm.18(1).2020.11

Pfeffer, J. (1972). Size and composition of corporateboards of directors: The organization and its environment. Administrative Science Quarterly, 17, 218-228.

Roberts, J., McNulty, T., \& Stiles, P. (2005). Beyond agency conceptions of the work of the non-executive director: Creating accountability in the boardroom. British Journal of Management, 16(1), 15-26.

Ujunwa, A. (2012). Board characteristics and financial performance of Nigerian quoted firms. Corporate Governance, 12(5), 656-674. 
Umukoro, O. E., Eluyela, D. F., Ozordi, E., Inua, O. I., \& Balogun, S. B. (2020). Nollywood Accounting and Financial Performance: evidence from Nigerian Cinemas. International Journal of Financial Research, 11(2), 271-280. https://doi.org/10.5430/ijfr.v11n2p271

Uwuigbe, O. R., \& Fakile, A. S. (2012). The effect of board size on the financial performance of banks in Nigeria, International Journal of Economics and Finance, 4(20), 260-267.

Uwuigbe, U., \& Olayinka, M. U. (2012). An Empirical Examination of the Relationship between Capital Structure and the Financial Performance of Firms in Nigeria. EuroEconomica, 31(1), 57-65.

Uwuigbe, U., \& Uadiale, O. M. (2012). An Empirical Examination of the Relationship between Capital Structure and the Financial Performance of Firms in Nigeria. EuroEconomica, 31(1).

Yermack, D. (1996). Higher Market Valuation of Companies with a Small Board of Directors. Journal of Financial Economics, 40(1), 185-211.

Yermack, D. (2006). Board Members and Company Value. Financial Markets Portfolio Management, 20(1), 33-47.

\section{Copyrights}

Copy right for this articleisretainedbytheauthor(s), with first publication rights granted to the journal.

This is an open-access article distributed under the terms and conditions of the Creative Commons Attribution license (http://creativecommons.org/licenses/by/4.0/). 